\title{
Continuous Flow Chlorination of Alkenyl lodides Promoted by Copper Tubing
}

\author{
Antoine Nitelet ${ }^{\mathrm{a}}$ \\ Vanessa Kairouz ${ }^{b}$ \\ Hélène Lebel ${ }^{* b}$ (D) \\ André B. Charette*b (iD) \\ Gwilherm Evano*a (D) \\ a Laboratoire de Chimie Organique, Service de Chimie et PhysicoChimie \\ Organiques, Université libre de Bruxelles (ULB), Avenue F. D. Roosevelt \\ 50, CP160/06, 1050 Brussels, Belgium \\ Gwilherm.Evano@ulb.be \\ ${ }^{\mathrm{b}}$ Centre in Green Chemistry and Catalysis, Faculty of Arts and Sciences, \\ Department of Chemistry, Université de Montréal, P.O. Box 6128, \\ Station Downtown, Montréal, Québec, H3C 3J7, Canada \\ andre.charette@umontreal.ca \\ helene.lebel@umontreal.ca
}

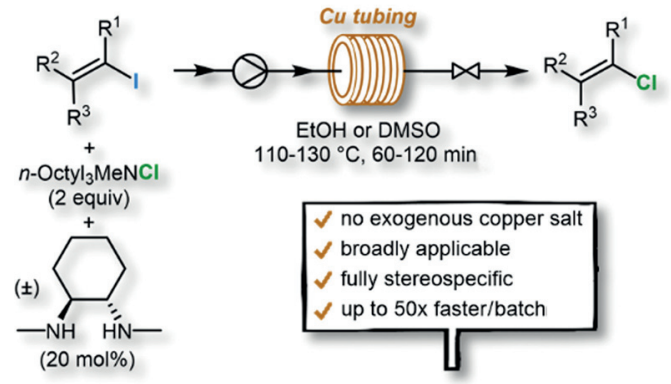

Despite these advantages, the halogen exchange typically requires 48 hours of reaction time to reach full conversion, which represents the main limitation of the process. Furthermore, any remaining traces of starting material significantly increases the level of difficulty of the purification step as it is quite challenging to separate the starting material from the desired product. A significant reduction in the reaction time would undeniably greatly improve the efficiency of this method. This goal should be achievable by transposing this reaction to continuous flow. Continuous flow chemistry has recently emerged as a powerful technology that increases mass and heat transfer, thus accelerating reaction processes considerably. ${ }^{5}$ Furthermore, the use of copper reactors for in situ generation of copper catalysts has been successfully reported for a number of transformations, including alkyne-azide cycloaddition, Ullmann condensation, Sonogashira coupling, decarboxylation reactions, and hydroxylation of aryl iodides. ${ }^{6}$ Inspired by Buchwald's copper-catalyzed aromatic Finkelstein reaction in continuous flow ${ }^{7}$ and on the basis of our combined interest in copper catalysis ${ }^{4 a, 8}$ and flow chemistry, ${ }^{9}$ we report herein a continuous flow synthesis of alkenyl chlorides from alkenyl iodides using a copper reactor.

The copper-catalyzed vinylic retro-Finkelstein reaction was studied using $\beta$-iodo-styrene (1a) as the model substrate. The reaction occurred when a heated PFA reactor coil in ethanol was used in the presence of an 8 bar back-pressure regulator (BPR). Aliquat $336^{\circledR}\left(n-\mathrm{Octyl}_{3} \mathrm{MeNCl}\right)$ was identified as a soluble chloride source in replacement of $\mathrm{Me}_{4} \mathrm{NCl}$ (used in the previously reported batch method) in combination with copper(I) iodide (10 mol\%) and trans- $N, N^{\prime}$-dimethylcyclohexane-1,2-diamine ( $20 \mathrm{~mol} \%)$ in ethanol to afford the chlorinated alkenyl iodide (Scheme 2). Conversion was low when the reactor coil was heated at $110{ }^{\circ} \mathrm{C}$ with a residence time of 120 minutes. Increasing the temperature did not lead to fruitful results, as extensive substrate degradation was observed when heating the reactor coil at $130{ }^{\circ} \mathrm{C}$ 

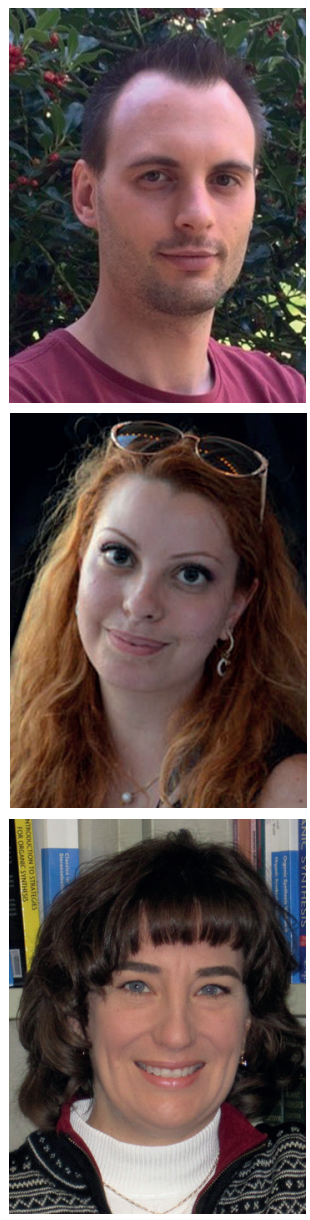

Hélène Lebel received her $\mathrm{PhD}$ from the Université de Montréal under the supervision of Prof. André B. Charette in 1998. She then joined the group of Eric N. Jacobsen at Harvard University as an NSERC postdoctoral fellow. She began her independent academic career at the Université de Montréal as an assistant professor in 1999, under an NSERC University Faculty Award. She was promoted to the rank of associate professor in 2005 ,

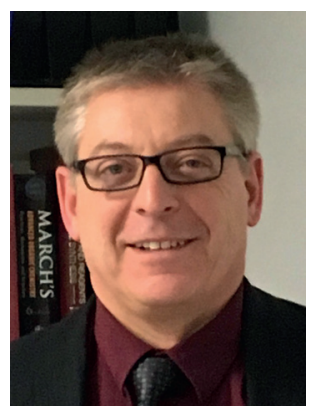

André B. Charette received his B.Sc. in 1983 from the Université de Montréal. He then moved south of the border to the University of Rochester to pursue graduate studies under the supervision of Robert K. Boeckman Jr. (M.Sc. in 1985 and Ph.D. in 1987). Following an NSERC postdoctoral fellowship at Harvard University with David A. Evans, he began his academic career, first at Université Laval (1989-1992) then at his alma mater, Université de Montréal, where was promoted to the rank of full professor in 1998 and where he

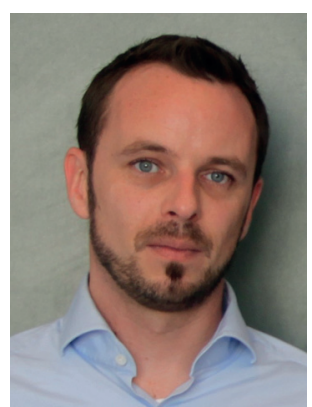

Gwilherm Evano was born in Paris in 1977 and studied chemistry at the Ecole Normale Supérieure. He received his Ph.D. from the Université Pierre et Marie Curie in 2002 under the supervision of Profs. François Couty and Claude Agami. After postdoctoral studies with Prof. James S. Panek at Boston Uni- ship in 2013, he pursued a Ph.D. in the same group, where his research focused on copper-catalyzed transformations, notably the development of a vinylic version of the Finkelstein reaction, and their use in natural product synthesis. Within the framework of a joint project between Profs. Lebel, Cha- rette, and Evano, he went twice to the Université de Montréal to develop the vinylic Finkelstein reaction in continuous flow. After graduating in December 2017, he then moved to INSA Rouen in Normandie (France) as a postdoctoral fellow in the group of Prof. Xavier Pannecoucke. well as the NSERC CREATE Program in Continuous Flow Science located at the Université de Montréal. Her versatile educational background in supramolecular chemistry, catalysis, green chemistry, biochemistry, and microfluidics, in addition

and full professor in 2010. The quality of her research has been recognized with many awards, including the Enantioselective Synthetic Chemistry Research Award in 2005, the Johnson \& Johnson Focused Funding Grant Award in 2008, the Merck Frosst Centre for Therapeutic Research Award in 2009, and the Clara Benson Award in 2014. She held the Canada Research Chair in Organometallic Catalysis (tier II) from 2006 to 2016.

currently serves as holder of a Canada Research Chair in Stereoselective Synthesis of Bioactive Molecules (2005-), co-director of the FRQNT Centre in Green Chemistry and Catalysis (2009-), co-director of the NSERC CREATE Program in Continuous Flow Science, and director of his Department of Chemistry (2014-). With a publication record that encompasses well over 220 articles in international journals, he has achieved worldwide recognition in the area of organic synthesis. He is widely recognized for conceptually

versity, he joined the CNRS as associate professor in 2004. He then moved to the Université libre de Bruxelles, where he has been the head of the Laboratory of Organic Chemistry since 2012. His research program currently focuses on natural/bioactive product synthesis, copper catalysis, and the chemis- to her extensive experience in training students enables her to understand and anticipate students' needs when it comes to using and maintaining flow infrastructure.

She has been the author of more than 60 publications as an independent researcher and has contributed to numerous book chapters. Her research program addresses the development of novel catalytic green processes and the discovery of recyclable reagents. More recently, her research program has included the study of novel, innovative continuous flow processes.

novel and practical approaches to the design of catalysts and reactions for the synthesis of cyclopropanes, heterocyclic derivatives, and greener functional group transformations using continuous flow synthesis. In addition, he has received more than twenty international awards, including the $\mathrm{CIC}$ Medal (2018), a doctorate honoris causa from INSA-Rouen (2015), the CSC Alfred Bader Award (2009), the Marie Victorin Award (2008), and an Arthur C. Cope Award (2007).

try of heteroatom-substituted alkynes and reactive intermediates. He has published more than 120 articles and 10 book chapters and has received several awards, the latest one being the 2017 Triennial Prize of the Belgian Royal Society of Chemistry. 
for 120 minutes of residence time. To improve the catalyst solubility, dioxane was introduced as a co-solvent, but this did not lead to any significant improvement.

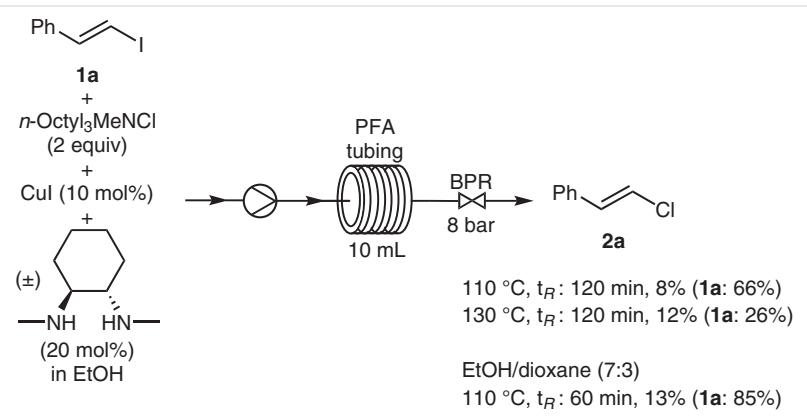

Scheme 2 Copper-catalyzed chlorination of alkenyl iodides in continuous flow using PFA reactor tubing

Facing little success using a PFA reactor coil, we then resorted to using a copper reactor coil. These reactors are known to be more resistant to high pressures and temperatures in addition to enabling in situ generation of the copper catalyst ${ }^{6}$ without the need of an external source of copper(I) iodide (Table 1). Full conversion was observed after 60 minutes of residence time without $\mathrm{CuI}$ (entries 1-3). The diamine ligand was, however, essential for obtaining the desired product (entry 4). Optimization with substrate 1a showed that the maximum yield was obtained at $130{ }^{\circ} \mathrm{C}$ and with 40 minutes residence time. Under these reaction conditions, a yield of $84 \%$ of $2 \mathbf{a}$ was achieved (entry 7). Importantly, the exact same yield was obtained when the reaction was scaled up to afford $3.5 \mathrm{~g}$ of product $\mathbf{2 a}$ as a single stereoisomer.

The optimized reaction conditions were then applied to the transformation of other substrates; representative examples are shown in Scheme 3. In most cases, the yields obtained in continuous flow were similar or superior to those obtained in batch, but with a significant reduction in the reaction time. ${ }^{4}$ With E-iodo-substituted alkenes, the maximum yields were achieved at $110{ }^{\circ} \mathrm{C}$ with a residence time of 60 minutes. In the case of products $\mathbf{2 b}, \mathbf{2 c}, \mathbf{2 e}$, and $\mathbf{2 h}$, DMSO was used as the solvent to favor a homogeneous system. In the case of more sterically hindered $Z$-iodo-substituted alkenes, it was necessary to heat the reaction at $120^{\circ} \mathrm{C}$ for 120 minutes of residence time. Under these conditions, the corresponding Z-chloro-substituted alkenes $\mathbf{2 i}$ 1 were obtained in good to excellent yields and, most importantly, without detectable presence of isomerization products. The chlorination was found to proceed equally well with aryl- and alkyl-substituted alkenyl iodides and was shown to tolerate electron-withdrawing (2c) and electrondonating (2e) groups, as well as acetal (21), silyl ether $(\mathbf{2 g}$, $\mathbf{2 m}$ ), and phthalimide ( $\mathbf{2 h}$ ) protecting groups. Notably, a labile allylic PMP ether $(\mathbf{2 k})$ remained untouched under these
Table 1 Optimization of the Continuous Flow Chlorination of Alkenyl lodides Promoted by Copper Tubing

\begin{tabular}{|c|c|c|c|}
\hline & & $\begin{array}{l}\text { ubing } \\
\mathrm{mL} \\
\mathrm{C}), \mathrm{t}_{R}\end{array}$ & ${ }_{2 a}{ }_{C l}$ \\
\hline Entry & Temp $\left({ }^{\circ} \mathrm{C}\right)$ & $t_{R}(\min )$ & Yield (\%) \\
\hline 1 & 110 & 120 & 43 \\
\hline 2 & 110 & 60 & 72 \\
\hline $3^{b}$ & 110 & 60 & 70 \\
\hline $4^{c}$ & 110 & 60 & 0 \\
\hline $5^{d}$ & 110 & 60 & 80 \\
\hline 6 & 130 & 30 & 83 \\
\hline 7 & 130 & 40 & $84\left(84^{e}, 84^{f}\right)$ \\
\hline 8 & 150 & 30 & 72 \\
\hline
\end{tabular}

a Yields determined by NMR; DMF used as internal standard.

b Using EtOH/dioxane, 7:3.

c Without the diamine ligand.

${ }^{\mathrm{d}}$ Using diamine ligand (40 mol\%).

e Isolated yield.

${ }^{\mathrm{f}}$ Isolated yield on a $3.5 \mathrm{~g}$ scale.

reaction conditions. As previously reported in batch, only moderate yields were obtained for the $\alpha$-substituted chloroalkene $\mathbf{2 m}$. When using continuous flow techniques, the temperature had to be increased to $130{ }^{\circ} \mathrm{C}$ to achieve full conversion in 120 minutes (47\% isolated yield). However, significant substrate decomposition was observed. This result is not surprising, as it has been stated that higher temperatures lead to the decomposition of the starting material.

The advantages of the continuous flow chlorination of alkenyl iodides promoted by copper tubing compared to our original procedure in batch are fairly evident when looking at the most important reaction parameters summarized in Table 2. Indeed, slightly higher yields (average yield of $78 \%$ in flow $v s 74 \%$ in batch) are obtained in flow with significantly reduced reaction time (1-2 h in flow vs $24-48$ $\mathrm{h}$ in batch) without the use of an external source of copper. Moreover, the reaction is more easily scaled up in flow compared to the batch process without any loss in yield. Finally, it should be mentioned that the optimized conditions require the reaction to be performed at temperatures exceeding the boiling point of the solvent $\left(110-130{ }^{\circ} \mathrm{C}\right.$ in ethanol); while this procedure is easily possible in continuous flow by using the copper reactor coil and an 8 bar back- 


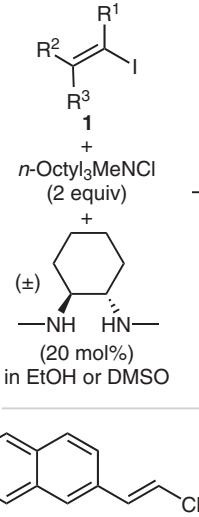

2b, $88 \%{ }^{a, b}$ 2e, $75 \%$ a,b<smiles>FC(F)(F)c1ccc(/C=C/Cl)cc1</smiles>
2c, $62 \%{ }^{a, b}$

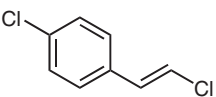

2d, $65 \%{ }^{\mathrm{b}}$<smiles>Cl/C=C/[PbH2]</smiles>

2f, $81 \%$ b

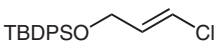

2 g, $91 \%^{\mathrm{b}}$<smiles>O=C1c2ccccc2C(=O)N1C/C=C/Cl</smiles>

2h, $85 \%$ a,b<smiles>CC(C)(C)OC/C=C\Cl</smiles>

$2 k, 88 \%{ }^{\circ}$

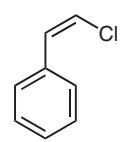

2i, $79 \%^{\mathrm{c}}$

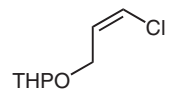

2I, $80 \%{ }^{c}$

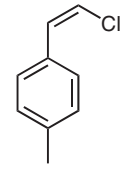

2j, $86 \%^{\mathrm{c}}$

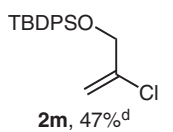<smiles>COc1ccc(/C=C/Cl)cc1</smiles>

Scheme 3 Scope of the continuous flow chlorination of alkenyl iodides promoted by copper tubing. ${ }^{\mathrm{a}}$ In DMSO; b $110^{\circ} \mathrm{C}, 60 \mathrm{~min} ;{ }^{\mathrm{C}} 120^{\circ} \mathrm{C}, 120$ $\min ;{ }^{d} 130^{\circ} \mathrm{C}, 120 \mathrm{~min}$.

pressure regulator, performing the reaction under the same conditions in batch requires a pressurized tube, which can be quite challenging and hazardous on a larger scale.

Table 2 Comparison of the Copper-Catalyzed Chlorination of Alkenyl lodides in Continuous Flow and in Batch

\begin{tabular}{llllll}
\hline & $\begin{array}{l}\text { Average } \\
\text { yield }\end{array}$ & $\begin{array}{l}\text { Reaction } \\
\text { time }\end{array}$ & $\begin{array}{l}\text { Exogenous } \\
\text { copper }\end{array}$ & $\begin{array}{l}\text { Pressure } \\
\text { handling }\end{array}$ & Scale-up \\
\hline $78 \%$ & $1-2 \mathrm{~h}$ & none & $\begin{array}{l}\text { copper } \\
\text { tubing }\end{array}$ & $\begin{array}{l}\text { identical } \\
\text { yield }\end{array}$ \\
\hline $74 \%$ & $24-48 \mathrm{~h}$ & Cul $)$ & $\begin{array}{l}\text { pressure } \\
\text { tube }\end{array}$ & $\begin{array}{l}\text { reduced } \\
\text { yield }\end{array}$ \\
\hline 5 & & & &
\end{tabular}

In conclusion, we have reported an easily accessible continuous flow synthesis of alkenyl chlorides from the corresponding readily available alkenyl iodides. The procedure was shown to be broadly applicable and compatible with a range of functional groups. The continuous flow copper-catalyzed chlorination of alkenyl iodides features several advantages compared to the batch process: these include the in situ generation of the copper catalyst from the copper tubing, an easy scale-up, slightly higher yields, operational simplicity when performing the halogen exchange above the boiling point of the solvent, and reduction in reaction times by a factor of 24-48. Further applications of this vinylic retro-Finkelstein reaction are under study and will be reported in due time.

The chlorination reactions were performed using a Vapourtec R-series continuous flow system equipped with a $10 \mathrm{~mL}$ heated copper reactor coil (1.00 mm I.D., $1.59 \mathrm{~mm}$ O.D.) and an 8 bar back-pressure regulator. All solvents were reagent grade. DMSO and dioxane over molecular sieves in AcroSeal ${ }^{\circledR}$ bottles were bought from Acros Organics and used as supplied. $\mathrm{CuI}$ (99.999\% purity) was purchased from $\mathrm{Al}-$ drich and used as supplied. All other reagents were used as supplied. Analytical TLC was performed by using $0.25 \mathrm{~mm}$ silica gel 60 -F plates. Visualization of the developed chromatogram was performed by using UV absorbance or aq $\mathrm{KMnO}_{4}$. Flash chromatography and filtrations were performed with silica gel (230-400 mesh). Yields refer to chromatographically and spectroscopically pure compounds, unless otherwise stated. ${ }^{1} \mathrm{H}$ NMR spectra were recorded using an internal deuterium lock at ambient temperature on Bruker 300 and JEOL 400 $\mathrm{MHz}$ spectrometers (internal reference, $\delta_{\mathrm{H}}=7.26, \mathrm{CDCl}_{3}$, relative to $\left.\delta_{\mathrm{TMS}}=0\right)$. Resonances that are either partially or fully obscured are denoted obscured (obs). ${ }^{13} \mathrm{C}$ NMR spectra were recorded at $75 \mathrm{MHz}$ using $\mathrm{CDCl}_{3}\left(\delta_{\mathrm{C}}=77.16\right)$ as internal reference. ${ }^{19} \mathrm{~F}$ NMR spectra were recorded at $377 \mathrm{MHz}$ using $\mathrm{C}_{6} \mathrm{~F}_{6}\left(\delta_{\mathrm{F}}=-164.92\right)$ as external reference. Melting points were recorded on a Stuart Scientific Analogue SMP11. IR spectra were recorded on a Bruker Alpha Spectrophotometer (ATR). High-resolution mass spectra were obtained on a Waters QTof API US, a Thermo Finnigan MAT 95XP, or a Waters XevoQTof spectrometer.

\section{(E)-(2-Chlorovinyl)benzene (2a)}

In an oven-dried $10 \mathrm{~mL}$ flask, (E)-(2-iodovinyl)benzene (115 mg, 0.50 $\mathrm{mmol}),( \pm)$-trans- $N, N^{\prime}$-dimethylcyclohexane-1,2-diamine $(16 \mu \mathrm{L}, 0.10$ $\mathrm{mmol})$, and Aliquat $336^{\circledR}(457 \mu \mathrm{L}, 1.00 \mathrm{mmol})$ were premixed in EtOH $(1 \mathrm{~mL})$ for $5 \mathrm{~min}$. The resulting reaction mixture was pumped into the copper reactor at $130^{\circ} \mathrm{C}$ for 40 min with a flow rate of $0.25 \mathrm{~mL} / \mathrm{min}$. Upon exiting the copper reactor, the reaction stream passed through a back-pressure regulator ( 8 bar) before being collected into a flask. The crude reaction mixture was diluted with EtOAc, filtered through a plug of silica gel and concentrated. The crude residue was finally purified by flash column chromatography (silica gel, pentane) to afford 2a.

Yield: $58 \mathrm{mg}$ ( $0.42 \mathrm{mmol}, 84 \%)$; colorless oil.

${ }^{1} \mathrm{H}$ NMR $\left(300 \mathrm{MHz}, \mathrm{CDCl}_{3}\right): \delta=7.37-7.28(\mathrm{~m}, 5 \mathrm{H}), 6.85(\mathrm{~d}, J=13.5 \mathrm{~Hz}$, $1 \mathrm{H}), 6.64(\mathrm{~d}, J=13.8 \mathrm{~Hz}, 1 \mathrm{H})$.

${ }^{13} \mathrm{C}$ NMR $\left(75 \mathrm{MHz}, \mathrm{CDCl}_{3}\right): \delta=135.0,133.4,128.9,128.3,126.3,118.8$.

The spectroscopic data correspond to those previously reported. ${ }^{2 \mathrm{~d}}$

\section{(E)-2-(2-Chlorovinyl)naphthalene (2b)}

In an oven-dried $10 \mathrm{~mL}$ flask, (E)-2-(2-iodovinyl)naphthalene (140 $\mathrm{mg}, 0.50 \mathrm{mmol}),( \pm)$-trans- $N, N^{\prime}$-dimethylcyclohexane-1,2-diamine $(16 \mu \mathrm{L}, 0.10 \mathrm{mmol})$, and Aliquat $336^{\circledR}(457 \mu \mathrm{L}, 1.00 \mathrm{mmol})$ were premixed in DMSO $(1 \mathrm{~mL})$ for $5 \mathrm{~min}$. The resulting reaction mixture was pumped into the copper reactor at $110{ }^{\circ} \mathrm{C}$ for $60 \mathrm{~min}$ with a flow rate 
of $0.166 \mathrm{~mL} / \mathrm{min}$. Upon exiting the fourth flow reactor, the reaction stream passed through a back-pressure regulator ( 8 bar) before being collected into a flask. The crude reaction mixture was diluted with $\mathrm{H}_{2} \mathrm{O}$ and extracted with $\mathrm{Et}_{2} \mathrm{O}(2 \times)$; the combined organic layers were dried $\left(\mathrm{MgSO}_{4}\right)$, filtered, and concentrated. The crude residue was finally purified by flash column chromatography (silica gel, pentane) to afford $\mathbf{2 b}$.

Yield: $83 \mathrm{mg}$ (0.44 mmol, $88 \%)$; white solid; $\mathrm{mp} 75{ }^{\circ} \mathrm{C}$.

${ }^{1} \mathrm{H}$ NMR $\left(300 \mathrm{MHz}, \mathrm{CDCl}_{3}\right): \delta=7.90-7.75(\mathrm{~m}, 3 \mathrm{H}), 7.70(\mathrm{~s}, 1 \mathrm{H}), 7.56-$ $7.41(\mathrm{~m}, 3 \mathrm{H}), 7.02(\mathrm{~d}, J=13.5 \mathrm{~Hz}, 1 \mathrm{H}), 7.79(\mathrm{~d}, J=13.8 \mathrm{~Hz}, 1 \mathrm{H})$.

${ }^{13} \mathrm{C}$ NMR $\left(75 \mathrm{MHz}, \mathrm{CDCl}_{3}\right): \delta=133.8,133.5,132.7,128.9,128.4,128.1$, 127.0, 126.7, 126.6, 123.4, 119.4.

The spectroscopic data correspond to those previously reported. ${ }^{10}$

\section{(E)-1-(2-Chlorovinyl)-4-(trifluoromethyl)benzene (2c)}

In an oven-dried $10 \mathrm{~mL}$ flask, (E)-1-(2-iodovinyl)-4-(trifluoromethyl)benzene (149 mg, $0.50 \mathrm{mmol}),( \pm)$-trans- $N, N^{\prime}$-dimethylcyclohexane-1,2-diamine (16 $\mu \mathrm{L}, 0.10 \mathrm{mmol})$, and Aliquat $336^{\circledR}(457 \mu \mathrm{L}, 1.00$ $\mathrm{mmol})$ were premixed in DMSO $(1 \mathrm{~mL})$ for $5 \mathrm{~min}$. The resulting reaction mixture was pumped into the copper reactor at $110{ }^{\circ} \mathrm{C}$ for $60 \mathrm{~min}$ with a flow rate of $0.166 \mathrm{~mL} / \mathrm{min}$. Upon exiting the fourth flow reactor, the reaction stream passed through a back-pressure regulator ( 8 bar) before being collected into a flask. The crude reaction mixture was diluted with $\mathrm{H}_{2} \mathrm{O}$ and extracted with $\mathrm{Et}_{2} \mathrm{O}(2 \times)$; the combined organic layers were dried $\left(\mathrm{MgSO}_{4}\right)$, filtered, and concentrated. The crude residue was finally purified by flash column chromatography (silica gel, pentane) to afford $\mathbf{2 c}$.

Yield: $64 \mathrm{mg}$ (0.31 mmol, 62\%); light yellow oil.

IR (ATR): 3074, 1614, 1412, 1324, 1165, 1123, 1109, 1067, 1017, 931, $845,823,795,755,728 \mathrm{~cm}^{-1}$.

${ }^{1} \mathrm{H}$ NMR $\left(300 \mathrm{MHz}, \mathrm{CDCl}_{3}\right): \delta=7.58(\mathrm{~d}, J=8.1 \mathrm{~Hz}, 2 \mathrm{H}), 7.40(\mathrm{~d}, J=8.1$ $\mathrm{Hz}, 2 \mathrm{H}), 6.86$ (d, $J=13.5 \mathrm{~Hz}, 1 \mathrm{H}), 6.75(\mathrm{~d}, J=13.5 \mathrm{~Hz}, 1 \mathrm{H})$.

${ }^{13} \mathrm{C}$ NMR (100 MHz, $\left.\mathrm{CDCl}_{3}\right): \delta=138.4,132.2,130.1(\mathrm{q}, J=32.3 \mathrm{~Hz})$, $126.4,125.9(\mathrm{q}, J=3.8 \mathrm{~Hz}), 124.1(\mathrm{q}, J=270.4 \mathrm{~Hz}), 121.6$.

${ }^{19} \mathrm{~F} \mathrm{NMR}\left(377 \mathrm{MHz}, \mathrm{CDCl}_{3}\right): \delta=-65.8(\mathrm{~s})$.

HRMS (EI): $m / z$ [M] $]^{+}$calcd for $\mathrm{C}_{9} \mathrm{H}_{6}{ }^{35} \mathrm{ClF}_{3}$ : 206.0105; found: 206.0106 .

\section{(E)-1-Chloro-4-(2-chlorovinyl)benzene (2d)}

In an oven-dried $10 \mathrm{~mL}$ flask, (E)-1-chloro-4-(2-iodovinyl)benzene (132 mg, $0.50 \mathrm{mmol}$ ), ( \pm )-trans- $N, N^{\prime}$-dimethylcyclohexane-1,2-diamine $(16 \mu \mathrm{L}, 0.10 \mathrm{mmol})$, and Aliquat $336^{\circledR}(457 \mu \mathrm{L}, 1.00 \mathrm{mmol})$ were premixed in $\mathrm{EtOH}(1 \mathrm{~mL})$ for $5 \mathrm{~min}$. The resulting reaction mixture was pumped into the copper reactor at $110{ }^{\circ} \mathrm{C}$ for $60 \mathrm{~min}$ with a flow rate of $0.16 \mathrm{~mL} / \mathrm{min}$. Upon exiting the fourth flow reactor, the reaction stream passed through a back-pressure regulator ( 8 bar) before being collected into a flask. The crude reaction mixture was diluted with EtOAc, filtered through a plug of silica gel and concentrated. The crude residue was finally purified by flash column chromatography (silica gel, pentane) to afford $\mathbf{2 d}$.

Yield: $56 \mathrm{mg}$ ( $0.33 \mathrm{mmol}, 65 \%)$; white solid; $\mathrm{mp} 33^{\circ} \mathrm{C}$.

IR (ATR): 1488, 1403, 1090, 1012, 944, 927, 832, $818 \mathrm{~cm}^{-1}$.

${ }^{1} \mathrm{H} \mathrm{NMR}\left(300 \mathrm{MHz}, \mathrm{CDCl}_{3}\right): \delta=7.29(\mathrm{~d}, J=8.4 \mathrm{~Hz}, 2 \mathrm{H}), 7.21(\mathrm{~d}, J=8.4$ $\mathrm{Hz}, 2 \mathrm{H}), 6.77$ (d, $J=13.8 \mathrm{~Hz}, 1 \mathrm{H}), 6.62(\mathrm{~d}, J=13.8 \mathrm{~Hz}, 1 \mathrm{H})$.

${ }^{13} \mathrm{C}$ NMR (75 MHz, $\mathrm{CDCl}_{3}$ ): $\delta=134.0,133.2,132.2,129.1,127.4,119.5$. HRMS (EI): $m / z$ [M] $]^{+}$calcd for $\mathrm{C}_{8} \mathrm{H}_{6}{ }^{35} \mathrm{Cl}_{2}: 171.9841$; found: 171.9851 .

\section{(E)-(2-Chlorovinyl)-4-methoxybenzene (2e)}

In an oven-dried $10 \mathrm{~mL}$ flask, (E)-(2-iodovinyl)-4-methoxybenzene (130 mg, $0.50 \mathrm{mmol}$ ), ( \pm )-trans- $N, N^{\prime}$-dimethylcyclohexane-1,2-diamine $(16 \mu \mathrm{L}, 0.10 \mathrm{mmol})$, and Aliquat $336^{\circledR}(457 \mu \mathrm{L}, 1.00 \mathrm{mmol})$ were premixed in DMSO $(1 \mathrm{~mL})$ for $5 \mathrm{~min}$. The resulting reaction mixture was pumped into the copper reactor at $110^{\circ} \mathrm{C}$ for 60 min with a flow rate of $0.166 \mathrm{~mL} / \mathrm{min}$. Upon exiting the fourth flow reactor, the reaction stream passed through a back-pressure regulator ( 8 bar) before being collected into a flask. The crude reaction mixture was diluted with $\mathrm{H}_{2} \mathrm{O}$ and extracted with $\mathrm{Et}_{2} \mathrm{O}(2 \times)$; the combined organic layers were dried $\left(\mathrm{MgSO}_{4}\right)$, filtered, and concentrated. The crude residue was finally purified by flash column chromatography (silica gel, hexane-EtOAc, 95:5) to afford $2 \mathbf{e}$.

Yield: $63 \mathrm{mg}$ ( $0.32 \mathrm{mmol}, 75 \%)$; light yellow oil.

${ }^{1} \mathrm{H}$ NMR (300 MHz, $\mathrm{CDCl}_{3}$ ): $\delta=7.23(\mathrm{~d}, J=8.4 \mathrm{~Hz}, 2 \mathrm{H}), 6.83(\mathrm{~d}, J=8.7$ $\mathrm{Hz}, 2 \mathrm{H}$ ), 6.77 (d, J= 13.8 Hz, $1 \mathrm{H}$ ), 6.50 (d, J = $13.5 \mathrm{~Hz}, 1 \mathrm{H}$ ), 3.80 (s, 1 $\mathrm{H})$.

${ }^{13} \mathrm{C}$ NMR $\left(75 \mathrm{MHz}, \mathrm{CDCl}_{3}\right): \delta=160.0,133.1,128.0,127.7,116.8,114.6$, 55.7.

The spectroscopic data correspond to those previously reported. ${ }^{2 c}$

\section{(E)-1-Chlorodec-1-ene (2f)}

In an oven-dried $10 \mathrm{~mL}$ flask, (E)-1-iododec-1-ene (133 mg, 0.50 $\mathrm{mmol}),( \pm)$-trans- $N, N^{\prime}$-dimethylcyclohexane-1,2-diamine $(16 \mu \mathrm{L}, 0.10$ $\mathrm{mmol})$, and Aliquat $336^{\circledR}(457 \mu \mathrm{L}, 1.00 \mathrm{mmol})$ were premixed in EtOH $(1 \mathrm{~mL})$ for $5 \mathrm{~min}$. The resulting reaction mixture was pumped into the copper reactor at $110{ }^{\circ} \mathrm{C}$ for $60 \mathrm{~min}$ with a flow rate of $0.166 \mathrm{~mL} / \mathrm{min}$. Upon exiting the fourth flow reactor, the reaction stream passed through a back-pressure regulator ( 8 bar) before being collected into a flask. The crude reaction mixture was diluted with EtOAc, filtered through a plug of silica gel and concentrated. The crude residue was finally purified by flash column chromatography (silica gel, pentane) to afford $\mathbf{2 f}$.

Yield: $71 \mathrm{mg}$ ( $0.41 \mathrm{mmol}, 81 \%)$; colorless oil.

IR (ATR): 2956, 2925, 2855, 1457, 1377, 931, 805, $721 \mathrm{~cm}^{-1}$.

${ }^{1} \mathrm{H}$ NMR (300 MHz, $\mathrm{CDCl}_{3}$ ): $\delta=5.96-5.84(\mathrm{~m}, 2 \mathrm{H}), 2.04$ (app qd, $J=$ $7.2,1.2 \mathrm{~Hz}, 2 \mathrm{H}), 1.41-1.20(\mathrm{~m}, 12 \mathrm{H}), 0.88(\mathrm{t}, J=6.9 \mathrm{~Hz}, 3 \mathrm{H})$.

${ }^{13} \mathrm{C} \mathrm{NMR}\left(75 \mathrm{MHz}, \mathrm{CDCl}_{3}\right): \delta=134.2,116.7,32.0,31.0,29.5,29.4,29.1$, $29.0,22.8,14.2$.

HRMS (EI): $m / z$ [M] ${ }^{+}$calcd for $\mathrm{C}_{10} \mathrm{H}_{19}{ }^{35} \mathrm{Cl}$ : 174.1170 ; found: 174.1178 .

\section{(E)-3-(tert-Butyldiphenylsiloxy)-1-chloroprop-1-ene (2g)}

In an oven-dried $10 \mathrm{~mL}$ flask, (E)-3-(tert-butyldiphenylsiloxy)-1-iodoprop-1-ene $(211 \mathrm{mg}, 0.50 \mathrm{mmol})$, ( \pm )-trans- $N, N^{\prime}$-dimethylcyclohexane-1,2-diamine $(16 \mu \mathrm{L}, 0.10 \mathrm{mmol})$, and Aliquat $336^{\circledR}(457 \mu \mathrm{L}$, $1.00 \mathrm{mmol}$ ) were premixed in EtOH $(1 \mathrm{~mL})$ for $5 \mathrm{~min}$. The resulting reaction mixture was pumped into the copper reactor at $110^{\circ} \mathrm{C}$ for 60 min with a flow rate of $0.166 \mathrm{~mL} / \mathrm{min}$. Upon exiting the fourth flow reactor, the reaction stream passed through a back-pressure regulator ( 8 bar) before being collected into a flask. The crude reaction mixture was diluted with EtOAc, filtered through a plug of silica gel, and concentrated. The crude residue was finally purified by flash column chromatography (silica gel, hexane-EtOAc, 98:2) to afford $\mathbf{2 g}$.

Yield: $150 \mathrm{mg}$ (0.45 mmol, 91\%); colorless oil.

IR (ATR): 2930, 2857, 1471, 1376, 1111, 1067, 1007, 962, 926, 822, $767,738,700,614 \mathrm{~cm}^{-1}$. 
${ }^{1} \mathrm{H}$ NMR $\left(300 \mathrm{MHz}, \mathrm{CDCl}_{3}\right): \delta=7.71(\mathrm{~d}, J=7.5 \mathrm{~Hz}, 4 \mathrm{H}), 7.50-7.38(\mathrm{~m}, 6$ H), $6.27(\mathrm{dt}, J=12.9,1.8 \mathrm{~Hz}, 1 \mathrm{H}), 6.03(\mathrm{dt}, J=13.2,4.8 \mathrm{~Hz}, 1 \mathrm{H}), 4.20$ (dd, $J=4.8,1.5 \mathrm{~Hz}, 2 \mathrm{H}), 1.10$ (s, $9 \mathrm{H})$.

${ }^{13} \mathrm{C}$ NMR $\left(75 \mathrm{MHz}, \mathrm{CDCl}_{3}\right): \delta=135.6,133.3,132.3,129.9,127.9,119.0$, $62.7,26.9,19.3$.

HRMS (EI): $m / z[\mathrm{M}]^{+}$calcd for $\mathrm{C}_{19} \mathrm{H}_{23}{ }^{35} \mathrm{ClOSi}$ : 330.1201; found: 330.1205 .

\section{(E)-1-Chloro-3-phthalimidoprop-1-ene (2h)}

In an oven-dried $10 \mathrm{~mL}$ flask, (E)-1-iodo-3-phthalimidoprop-1-ene (156 mg, $0.50 \mathrm{mmol}$ ), ( \pm )-trans- $N, N^{\prime}$-dimethylcyclohexane-1,2-diamine $(16 \mu \mathrm{L}, 0.10 \mathrm{mmol})$, and Aliquat $336^{\circledR}(457 \mu \mathrm{L}, 1.00 \mathrm{mmol})$ were premixed in DMSO $(1 \mathrm{~mL})$ for $5 \mathrm{~min}$. The resulting reaction mixture was pumped into the copper reactor at $110^{\circ} \mathrm{C}$ for $60 \mathrm{~min}$ with a flow rate of $0.166 \mathrm{~mL} / \mathrm{min}$. Upon exiting the fourth flow reactor, the reaction stream passed through a back-pressure regulator ( 8 bar) before being collected into a flask. The crude reaction mixture was diluted with $\mathrm{H}_{2} \mathrm{O}$ and extracted with $\mathrm{Et}_{2} \mathrm{O}(2 \times)$; the combined organic layers were dried $\left(\mathrm{MgSO}_{4}\right)$, filtered, and concentrated. The crude residue was finally purified by flash column chromatography (silica gel, hexane-EtOAc, 80:20) to afford $\mathbf{2 h}$.

Yield: $95 \mathrm{mg}$ (0.42 mmol, 85\%); white solid; $\mathrm{mp} 102{ }^{\circ} \mathrm{C}$.

IR (ATR): 3078, 1703, 1429, 1393, 1345, 1120, 1044, 941, 798, 717 , $614 \mathrm{~cm}^{-1}$.

${ }^{1} \mathrm{H}$ NMR (300 MHz, $\mathrm{CDCl}_{3}$ ): $\delta=7.85(\mathrm{dd}, J=5.4,3 \mathrm{~Hz}, 2 \mathrm{H}), 7.72(\mathrm{dd}, J=$ $5.7,3 \mathrm{~Hz}, 2 \mathrm{H}), 6.35(\mathrm{~d}, J=13.5 \mathrm{~Hz}, 1 \mathrm{H}), 6.00(\mathrm{dt}, J=13.2,7.2 \mathrm{~Hz}, 1 \mathrm{H})$, $4.26(\mathrm{dd}, J=6.3,0.6 \mathrm{~Hz}, 2 \mathrm{H})$.

${ }^{13} \mathrm{C}$ NMR $\left(75 \mathrm{MHz}, \mathrm{CDCl}_{3}\right): \delta=167.7,134.3,132.1,126.9,123.6,123.5$, 37.4.

HRMS (ESI): $m / z[\mathrm{M}+\mathrm{H}]^{+}$calcd for $\mathrm{C}_{11} \mathrm{H}_{9}{ }^{35} \mathrm{ClNO}_{2}$ : 222.0316; found: 222.0318 .

\section{(Z)-(2-Chlorovinyl)benzene (2i)}

In an oven-dried $10 \mathrm{~mL}$ flask, (Z)-(2-iodovinyl)benzene (115 mg, 0.50 mmol), ( \pm )-trans- $N, N^{\prime}$-dimethylcyclohexane-1,2-diamine ( $16 \mu \mathrm{L}, 0.10$ $\mathrm{mmol})$, and Aliquat $336^{\circledR}(457 \mu \mathrm{L}, 1.00 \mathrm{mmol})$ were premixed in EtOH $(1 \mathrm{~mL})$ for $5 \mathrm{~min}$. The resulting reaction mixture was pumped into the copper reactor at $120{ }^{\circ} \mathrm{C}$ for $120 \mathrm{~min}$ with a flow rate of 0.083 $\mathrm{mL} / \mathrm{min}$. Upon exiting the fourth flow reactor, the reaction stream passed through a back-pressure regulator ( 8 bar) before being collected into a flask. The crude reaction mixture was diluted with EtOAc, filtered through a plug of silica gel, and concentrated. The crude residue was finally purified by flash column chromatography (silica gel, pentane) to afford $2 \mathbf{i}$.

Yield: $54 \mathrm{mg}$ ( $0.39 \mathrm{mmol}, 79 \%)$; colorless oil.

IR (ATR): 3025, 1617, 1491, 1445, 1346, 926, 846, 772, 722, 689, 658 $\mathrm{cm}^{-1}$.

${ }^{1} \mathrm{H}$ NMR $\left(300 \mathrm{MHz}, \mathrm{CDCl}_{3}\right): \delta=7.67(\mathrm{~d}, J=7.2 \mathrm{~Hz}, 2 \mathrm{H}), 7.41-7.29(\mathrm{~m}, 3$ $\mathrm{H}), 6.64(\mathrm{~d}, J=8.1 \mathrm{~Hz}, 1 \mathrm{H}), 6.27(\mathrm{~d}, J=8.1 \mathrm{~Hz}, 1 \mathrm{H})$.

${ }^{13} \mathrm{C}$ NMR $\left(75 \mathrm{MHz}, \mathrm{CDCl}_{3}\right): \delta=134.3,129.4,129.3,128.4,128.3,117.7$. HRMS (EI): $m / z$ [M] ${ }^{+}$calcd for $\mathrm{C}_{8} \mathrm{H}_{7}{ }^{35} \mathrm{Cl}$ : 138.0231 ; found: 138.0239 .

\section{(Z)-1-(2-Chlorovinyl)-4-methylbenzene (2j)}

In an oven-dried $10 \mathrm{~mL}$ flask, (Z)-(2-iodovinyl)-4-methylbenzene (122 mg, $0.50 \mathrm{mmol}),( \pm)$-trans- $N, N^{\prime}$-dimethylcyclohexane-1,2-diamine $(16 \mu \mathrm{L}, 0.10 \mathrm{mmol})$, and Aliquat $336^{\circledR}(457 \mu \mathrm{L}, 1.00 \mathrm{mmol})$ were premixed in $\mathrm{EtOH}(1 \mathrm{~mL})$ for $5 \mathrm{~min}$. The resulting reaction mixture was pumped into the copper reactor at $120^{\circ} \mathrm{C}$ for $120 \mathrm{~min}$ with a flow rate of $0.083 \mathrm{~mL} / \mathrm{min}$. Upon exiting the fourth flow reactor, the reaction stream passed through a back-pressure regulator ( 8 bar) before being collected into a flask. The crude reaction mixture was diluted with EtOAc, filtered through a plug of silica gel, and concentrated. The crude residue was finally purified by flash column chromatography (silica gel, pentane) to afford $\mathbf{2 j}$.

Yield: $66 \mathrm{mg}$ ( $0.43 \mathrm{mmol}, 86 \%)$; colorless oil.

IR (ATR): 2922, 1615, 1509, 1448, 1344, 1173, 1120, 856, 821, 786, $730,694,621 \mathrm{~cm}^{-1}$.

${ }^{1} \mathrm{H} \mathrm{NMR}\left(300 \mathrm{MHz}, \mathrm{CDCl}_{3}\right): \delta=7.57(\mathrm{~d}, J=8.1 \mathrm{~Hz}, 2 \mathrm{H}), 7.18(\mathrm{~d}, J=8.1$ $\mathrm{Hz}, 2 \mathrm{H}), 6.60(\mathrm{~d}, J=8.1 \mathrm{~Hz}, 1 \mathrm{H}), 6.21(\mathrm{~d}, J=8.1 \mathrm{~Hz}, 1 \mathrm{H}), 2.36(\mathrm{~s}, 3 \mathrm{H})$.

${ }^{13} \mathrm{C} \mathrm{NMR}\left(75 \mathrm{MHz}, \mathrm{CDCl}_{3}\right): \delta=138.3,131.5,129.3,129.3,129.1,116.8$, 21.5.

HRMS (EI): $m / z$ [M] $]^{+}$calcd for $\mathrm{C}_{9} \mathrm{H}_{9}{ }^{35} \mathrm{Cl}$ : 152.0387; found: 152.0393 .

\section{(Z)-1-Chloro-3-(4-methoxyphenoxy)prop-1-ene (2k)}

In an oven-dried $10 \mathrm{~mL}$ flask, (Z)-1-iodo-3-(4-methoxy)phenyloxyprop-1-ene (152 mg, $0.50 \mathrm{mmol}),( \pm)$-trans- $N, N^{\prime}$-dimethylcyclohexane-1,2-diamine (16 $\mu \mathrm{L}, 0.10 \mathrm{mmol})$, and Aliquat $336^{\circledR}(457 \mu \mathrm{L}, 1.00$ $\mathrm{mmol}$ ) were premixed in EtOH $(1 \mathrm{~mL})$ for $5 \mathrm{~min}$. The resulting reaction mixture was pumped into the copper reactor at $120^{\circ} \mathrm{C}$ for 120 min with a flow rate of $0.083 \mathrm{~mL} / \mathrm{min}$. Upon exiting the fourth flow reactor, the reaction stream passed through a back-pressure regulator ( 8 bar) before being collected into a flask. The crude reaction mixture was diluted with EtOAc, filtered through a plug of silica gel, and concentrated. The crude residue was finally purified by flash column chromatography (silica gel, pentane- $\mathrm{Et}_{2} \mathrm{O}, 98: 2$ ) to afford $\mathbf{2 k}$.

Yield: $94 \mathrm{mg}$ (0.44 mmol, 88\%); colorless oil.

IR (ATR): 2833, 1506, 1462, 1227, 1181, 1107, 1039, 823, 751, $700 \mathrm{~cm}^{-1}$. ${ }^{1} \mathrm{H}$ NMR $\left(300 \mathrm{MHz}, \mathrm{CDCl}_{3}\right): \delta=6.85(\mathrm{~s}, 4 \mathrm{H}), 6.23(\mathrm{dt}, J=7.2,1.8 \mathrm{~Hz}, 1$ $\mathrm{H}), 6.05(\mathrm{dt}, J=7.2,1.5 \mathrm{~Hz}, 1 \mathrm{H}), 4.72(\mathrm{dd}, J=5.7,1.8 \mathrm{~Hz}, 2 \mathrm{H}), 3.77(\mathrm{~s}, 3$ H).

${ }^{13} \mathrm{C}$ NMR $\left(75 \mathrm{MHz}, \mathrm{CDCl}_{3}\right): \delta=154.3,152.4,128.4,120.7,115.8,114.8$, 64.4, 55.7 .

HRMS (EI): $m / z[M]^{+}$calcd for $\mathrm{C}_{10} \mathrm{H}_{11}{ }^{35} \mathrm{ClO}_{2}$ : 198.0442; found: 198.0452 .

\section{(Z)-1-Chloro-3-(tetrahydropyran-2-yloxy)prop-1-ene (21)}

In an oven-dried $10 \mathrm{~mL}$ flask, (Z)-1-iodo-3-(tetrahydropyran-2yloxy)prop-1-ene (134 mg, $0.50 \mathrm{mmol}),( \pm)$-trans- $N, N^{\prime}$-dimethylcyclohexane-1,2-diamine ( $16 \mu \mathrm{L}, 0.10 \mathrm{mmol})$, and Aliquat $336^{\circledR}(457 \mu \mathrm{L}$, $1.00 \mathrm{mmol}$ ) were premixed in EtOH $(1 \mathrm{~mL})$ for $5 \mathrm{~min}$. The resulting reaction mixture was pumped into the copper reactor at $120^{\circ} \mathrm{C}$ for $120 \mathrm{~min}$ with a flow rate of $0.083 \mathrm{~mL} / \mathrm{min}$. Upon exiting the fourth flow reactor, the reaction stream passed through a back-pressure regulator ( 8 bar) before being collected into a flask. The crude reaction mixture was diluted with EtOAc, filtered through a plug of silica gel and concentrated. The crude residue was finally purified by flash column chromatography (silica gel, pentane- $\mathrm{Et}_{2} \mathrm{O}, 80: 20$ ) to afford 21.

Yield: $71 \mathrm{mg}$ ( $0.40 \mathrm{mmol}, 80 \%)$; brown oil.

IR (ATR): 2942, 1634, 1454, 1351, 1201, 1156, 1120, 1070, 1029, 964, $906,870,815,733,683 \mathrm{~cm}^{-1}$.

${ }^{1} \mathrm{H}$ NMR $\left(300 \mathrm{MHz}, \mathrm{CDCl}_{3}\right): \delta=6.15(\mathrm{dt}, J=7.2,1.8 \mathrm{~Hz}, 1 \mathrm{H}$ ), 5.98 (app $\mathrm{dd}, J=12.9,6.3 \mathrm{~Hz}, 1 \mathrm{H}$ ), $4.65(\mathrm{t}, J=3.6 \mathrm{~Hz}, 1 \mathrm{H}$ ), 4.41 (A of ABXY system, $J=13.3,5.6,1.7 \mathrm{~Hz}, 1 \mathrm{H}$ ), 4.26 (B of ABXY system, $J=13.3,6.4,1.6$ $\mathrm{Hz}, 1 \mathrm{H}), 3.88(\mathrm{~m}, 1 \mathrm{H}), 3.53(\mathrm{~m}, 1 \mathrm{H}), 1.88-1.47(\mathrm{~m}, 6 \mathrm{H})$.

${ }^{13} \mathrm{C}$ NMR $\left(75 \mathrm{MHz}, \mathrm{CDCl}_{3}\right): \delta=129.0,120.1,98.7,62.9,62.5,30.7,25.5$, 19.6. 
HRMS (ESI): $m / z[M]^{+}$calcd for $\mathrm{C}_{8} \mathrm{H}_{13}{ }^{35} \mathrm{ClO}_{2}: 176.0599$; found: 176.0609.

\section{1-(tert-Butyldiphenylsiloxy)-2-chloroprop-2-ene (2m)}

In an oven-dried $10 \mathrm{~mL}$ flask, 1-(tert-butyldiphenylsiloxy)-2-iodoprop-2-ene ( $211 \mathrm{mg}, 0.50 \mathrm{mmol}),( \pm)$-trans- $N, N^{\prime}$-dimethylcyclohexane-1,2-diamine $(16 \mu \mathrm{L}, 0.10 \mathrm{mmol})$, and Aliquat $336^{\circledR}(457 \mu \mathrm{L}, 1.00$ $\mathrm{mmol}$ ) were premixed in DMSO $(1 \mathrm{~mL})$ for $5 \mathrm{~min}$. The resulting reaction mixture was pumped into the copper reactor at $130{ }^{\circ} \mathrm{C}$ for 120 min with a flow rate of $0.083 \mathrm{~mL} / \mathrm{min}$. Upon exiting the fourth flow reactor, the reaction stream passed through a back-pressure regulator ( 8 bar) before being collected into a flask. The crude reaction mixture was diluted with $\mathrm{H}_{2} \mathrm{O}$ and extracted with $\mathrm{Et}_{2} \mathrm{O}(2 \times)$; the combined organic layers were dried $\left(\mathrm{MgSO}_{4}\right)$, filtered, and concentrated. The crude residue was finally purified by flash column chromatography (silica gel, pentane) to afford $\mathbf{2 m}$.

Yield: $76 \mathrm{mg}$ ( $0.23 \mathrm{mmol}, 47 \%)$; colorless oil.

IR (ATR): 2931, 2857, 1647, 1472, 1427, 1111, 1089, 885, 824, 738, $700,613 \mathrm{~cm}^{-1}$.

${ }^{1} \mathrm{H}$ NMR $\left(300 \mathrm{MHz}, \mathrm{CDCl}_{3}\right): \delta=7.71-7.64(\mathrm{~m}, 4 \mathrm{H}), 7.49-7.36(\mathrm{~m}, 6 \mathrm{H})$, $5.66(\mathrm{~d}, J=1.5 \mathrm{~Hz}, 1 \mathrm{H}), 5.34(\mathrm{~d}, J=1.5 \mathrm{~Hz}, 1 \mathrm{H}), 4.18(\mathrm{t}, J=1.5 \mathrm{~Hz}, 2 \mathrm{H})$, $1.09(\mathrm{~s}, 9 \mathrm{H})$

${ }^{13} \mathrm{C}$ NMR $\left(75 \mathrm{MHz}, \mathrm{CDCl}_{3}\right): \delta=140.0,135.6,133.1,130.1,128.0,110.9$, $66.3,26.9,19.4$.

HRMS (EI): $m / z[\mathrm{M}]^{+}$calcd for $\mathrm{C}_{19} \mathrm{H}_{23}{ }^{35} \mathrm{ClOSi}$ : 330.1201; found: 330.1211.

\section{Funding Information}

This research was supported by the Fonds pour la formation à la Recherche dans l'Industrie et dans l'Agriculture (F.R.I.A., graduate fellowship to A.N.), the Natural Science and Engineering Research Council of Canada (NSERC) under the CREATE Training Program in Continuous Flow Science (CREATE 449307-2014), and the 'G-3 des universités francophones' (Chimie en flux continu et catalyse - C3F).

\section{Supporting Information}

Supporting information for this article is available online at https://doi.org/10.1055/s-0037-1610398.

\section{References}

(1) For representative examples, see: (a) Takai, K.; Nitta, K.; Utimoto, K.J. Am. Chem. Soc. 1986, 108, 7408. (b) Stork, G.; Zhao, K. Tetrahedron Lett. 1989, 30, 2173. (c) Kawaguchi, S.-i.; Ogawa, A. Org. Lett. 2010, 12, 1893. (d) Chan, T. H.; Fleming, I. Synthesis 1979, 761. (e) Stamos, D. P.; Taylor, A. G.; Kishi, Y. Tetrahedron Lett. 1996, 37, 8647. (f) Arefolov, A.; Langille, N. F.; Panek, J. S. Org. Lett. 2001, 3, 3281. (g) Ilardi, E. A.; Stivala, C. E.; Zakarian, A. Org. Lett. 2008, 10, 1727. (h) Jung, M.; Light, L. A. Tetrahedron Lett. 1982, 23, 3851. (i) Darwish, A.; Chong, J. M. Tetrahedron
2012, 68, 654. (j) Das, J. P.; Sujit, R. J. Org. Chem. 2002, 67, 7861. (k) Kulbitski, K.; Nisnevich, G.; Gandelman, M. Adv. Synth. Catal. 2011, 353, 1438.

(2) For representative examples, see: (a) Williams, D. R.; Nishitani, K.; Bennett, W.; Sit, S. Y. Tetrahedron Lett. 1981, 22, 3745. (b) Miller, R. B.; McGarvey, G. J. Org. Chem. 1978, 43, 4424. (c) Barluenga, J.; Moriel, P.; Aznar, F.; Valdes, C. Adv. Synth. Catal. 2006, 348, 347. (d) Bull, J. A.; Mousseau, J. J.; Charette, A. B. Org. Lett. 2008, 10, 5485. (e) Telvekar, V. N.; Takale, B. S. Tetrahedron Lett. 2011, 52, 2394.

(3) For recent reviews on aromatic and vinylic Finkelstein reactions, see: (a) Sheppard, T. D. Org. Biomol. Chem. 2009, 7, 1043. (b) Evano, G.; Nitelet, A.; Thilmany, P.; Dewez, D. F. Front. Chem. 2018, 6, 114.

(4) (a) Nitelet, A.; Evano, G. Org. Lett. 2016, 18, 1904. (b) Nitelet, A.; Jouvin, K.; Evano, G. Tetrahedron 2016, 72, 5972.

(5) (a) Newman, S. G.; Jensen, K. F. Green Chem. 2013, 15, 1456. (b) Gutmann, B.; Kappe, C. O. J. Flow Chem. 2017, 7, 65. (c) Morse, P. D.; Beingessner, R. L.; Jamison, T. F. Isr. J. Chem. 2017, 57, 218. (d) Plutschack, M. B.; Pieber, B.; Gilmore, K.; Seeberger, P. H. Chem. Rev. 2017, 117, 11796. (e) Wirth, T. Angew. Chem. Int. Ed. 2017, 56, 682.

(6) (a) Bogdan, A. R.; Sach, N. W. Adv. Synth. Catal. 2009, 351, 849. (b) Ceylan, S.; Klande, T.; Vogt, C.; Friese, C.; Kirschning, A. Synlett 2010, 2009. (c) Bogdan, A. R.; James, K. Org. Lett. 2011, 13, 4060. (d) Zhang, Y.; Jamison, T. F.; Patel, S.; Mainolfi, N. Org. Lett. 2011, 13, 280. (e) Tan, L.-M.; Sem, Z.-Y.; Chong, W.-Y.; Liu, X.; Hendra; Kwan, W. L.; Lee, C.-L. K. Org. Lett. 2013, 15, 65. (f) Cyr, P.; Charette, A. B. Synlett 2014, 25, 1409. (g) Bao, J.; Tranmer, G. K. Chem. Commun. 2015, 51, 3037. (h) Nuyts, K.; Ceulemans, M.; Parac-Vogt, T. N.; Bultynck, G.; De Borggraeve, W. M. Tetrahedron Lett. 2015, 56, 1687.

(7) Chen, M.; Ichikawa, S.; Buchwald, S. L. Angew. Chem. Int. Ed. 2015, 54, 263.

(8) For representative contributions, see: (a) Coste, A.; Karthikeyan, G.; Couty, F.; Evano, G. Angew. Chem. Int. Ed. 2009, 48, 4381. (b) Coste, A.; Couty, F.; Evano, G. Org. Lett. 2009, 11, 4454. (c) Jouvin, K.; Couty, F.; Evano, G. Org. Lett. 2010, 12, 3272. (d) Evano, G.; Tadiparthi, K.; Couty, F. Chem. Commun. 2011, 47, 179. (e) Laouiti, A.; Rammah, M. M.; Rammah, M. B.; Marrot, J.; Couty, F.; Evano, G. Org. Lett. 2012, 14, 6. (f) Jouvin, K.; Bayle, A.; Legrand, F.; Evano, G. Org. Lett. 2012, 14, 1652. (g) Pradal, A.; Evano, G. Chem. Commun. 2014, 50, 11907. (h) Theunissen, C.; Wang, J.; Evano, G. Chem. Sci. 2017, 8, 3465.

(9) For representative contributions, see: (a) Lebel, H.; Piras, H.; Borduy, M. ACS Catal. 2016, 6, 1109. (b) Rullière, P.; Cyr, P.; Charette, A. B. Org. Lett. 2016, 18, 1988. (c) Audubert, C.; Gamboa Marin, O. J.; Lebel, H. Angew. Chem. Int. Ed. 2017, 56, 6294. (d) Audubert, C.; Lebel, H. Org. Lett. 2017, 19, 4407. (e) Lévesque, E.; Laporte, S. T.; Charette, A. B. Angew. Chem. Int. Ed. 2017, 56, 837. (f) Rullière, P.; Benoit, G.; Allouche, E. M. D.; Charette, A. B. Angew. Chem. Int. Ed. 2018, 57, 5777. (g) Sayes, M.; Benoit, G.; Charette, A. B. Angew. Chem. Int. Ed. 2018, 57, 13514.

(10) Matsuda, T.; Suzuki, K.; Miura, N. Adv. Synth. Catal. 2013, 355, 3396. 